\title{
ACCESSORY THYROID GLAND OF THE LATERAL NECK
}

\author{
Sengul Ilker, ${ }^{1,2}$ Sengul Demet ${ }^{3}$ \\ ${ }^{1}$ Division of Endocrine Surgery, Giresun University Faculty of Medicine, Giresun, Turkey \\ ${ }^{2}$ Department of General Surgery, Giresun University Faculty of Medicine, Giresun, Turkey \\ ${ }^{3}$ Department of Pathology, Giresun University Faculty of Medicine, Giresun, Turkey
}

Primljen/Received 01. 02. 2019. god.

A 34-year-old Turkish woman presented with a left-sided cervical accessory thyroid gland. Her B-Mode thyroid ultrasonography exhibited an accessory thyroid parenchyma adjacent to the inferolateral border of left lobe of the thyroid gland (Figure 1a). Fine-needle aspiration (FNA) cytology (FNAC) is a frequently used primary diagnostic procedure worldwide due to its preciseness, easiness, non-invasiveness, possessing very little complications and low cost $(1,2)$. The thyroid gland ectopia and accessory thyroid tissue are two patterns of the abnormal thyroid gland migration. Ectopic thyroid gland is a rare phenomenon and described as a functioning thyroid tissue in an aberrant area along the embryological descending line of the thyroid gland. Its most common form is known as lingual thyroid, accounting for $90 \%$. Aproximately $70 \%$ of patients will exposed to the hormonal status of subclinical hypothyroidism (3). These phenomenon may later undergo a malignant transformation (4). An accessory thyroid gland is determined as a permanence of the thyroidal parenchyma anywhere from the base of the tongue to the thyroid isthmus, with the majority of the functional thyroid in its normal pretracheal area. The incidence of accessory thyroid gland is unknown (3). Of 58 cadavers just one (1/58) was detected as the accessory thyroid gland on the thyroid cartilage by Braun et al (3). Radkowski et al (5) performed thyroid ultra-

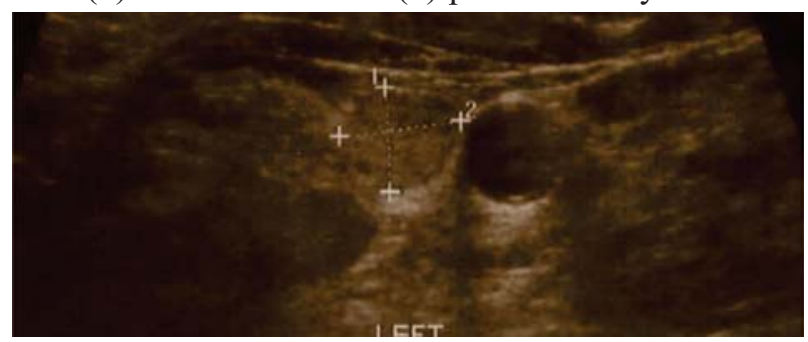

Figure 1a. The photograph of B-Mode ultrasonography, exhibiting a left-sided accessory thyroid parenchyma and its location
Prihvaćen/Accepted 28. 02. 2019. god.

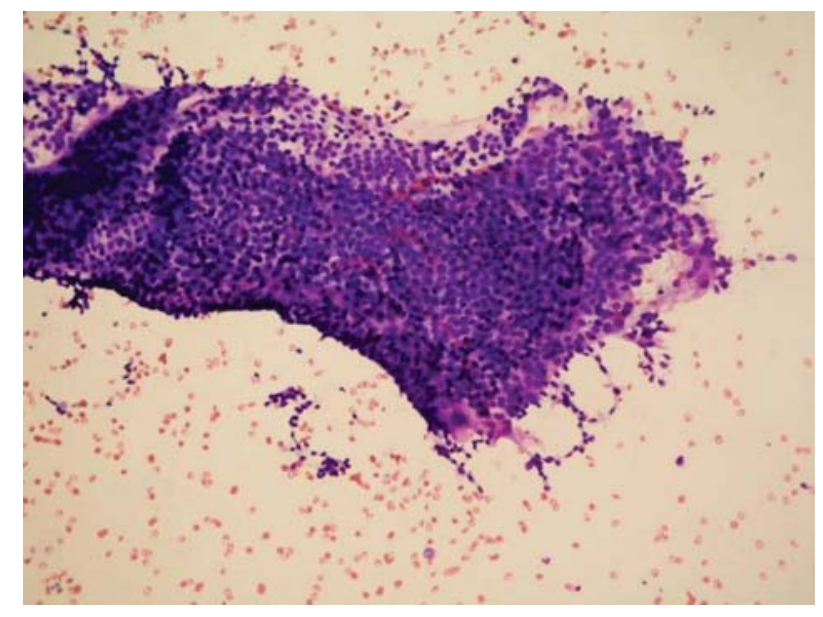

Figure 1b. The photomicrograph, exhibiting a huge cellular cluster, composed of the thyrocytes in a benign nature (Haematoxylin and Eosin,

Original magnification, 100x)

sonography on 230 cases of the throglossal duct cyst and detected four cases $(4 / 230)$ with the accessory thyroid tissue and three (3/230) with the ectopic thyroid gland. Therefore, they propunded the possibility of their equality in the incidence. The accessory thyroid glands are classified into five groups, based on their anatomical location: (1) cranial, (2) caudal, (3) lateral, (4) ventral, and (5) dorsal glands. They usually are founded along the former course of the thyroglossal duct and emigrate laterally (6). Pyramidal lobes, superior accessory thyroids, retrotracheal, inferior/lateral extensions or extrusions are involved in the reasons of the recurrent thyroid diseases as the anomalies of the gland. Richards et al (3) asserted both thyroid gland ectopia and accessory thyroid tissue being vulnerable to the same potential diseases as a normally-situated thyroid gland. An accessory thyroid gland do not lead to clinical complication except in cases of the pathologic conditions such as goitre, malignancy, and the others. A thyroid FNA were planned, 
performed and its cytopathologic evaluation with Haematoxylin and Eosin revealed a huge cellular cluster including the benign thyrocytes (Figure 1b). Therefore, a clinical follow-up was suggested for the present case, after a benign FNAC. Conclusively, education, training, and cognition of the thyroid embryology and anatomy and its associated variations and anomalies are very much essential for these kinds of the cases and it will lead to increasing the level of awareness.

\section{Abbreviations \\ FNA - Fine-needle aspiration \\ FNAC - Fine-needle aspiration cytology}

\section{REFERENCES}

1. Sengul D, Sengul I. Fine-needle aspiration biopsy and its minimal and/or rare potential risks and complications. Surg Chron. 2011; 16(1): 63.

2. Sengul I, Sengul D, Onursever A, Mocan G. A retrospective diagnostic analysis of 52 cases of fine - needle aspiration biopsy of thyroid which were performed in the first year of a state hospital. Endokrinolojide Diyalog. 2009; 6(3): 147-50.

3. Richards PS, Ahuja AT, King AD. Clinics in diagnostic imaging (101): Multinodular accessory thyroid tissue. Singapore Med J. 2004; 45(11): 542-5; quiz 546.

\section{Correspondence to/Autor za korespondenciju}

Ilker SENGUL, M. D.

The Founder Vice Dean, Associated Professor of General Surgery

The Founder Chairman, Division of Endocrine Surgery The Founder Chairman, Department of General Surgery Vice Chair, Department of Surgical Sciences

Giresun University Faculty of Medicine

Nizamiye Compound, Mumcular Avenue

TR28100 Giresun, TURKEY

Pho Deanery: +90 (454) 3101600

GSM: +90 (507) 4804377

Fax: +90 (454) 3101699

Email: ilker.sengul.52@gmail.com

\section{Acknowledgements}

No funding is used for the present work. All authors contributed equally and were involved in writing the paper and finally approved the submitted and published versions without any conflict of interest.

\section{DECLARATION OF INTEREST}

The authors declare that there are no conflicts of interest.

\section{Licensing}

This work is licensed under a Creative Commons Attribution 4.0 International (CC BY 4.0) License.

4. Ranade AV, Rai R, Pai MM, Nayak SR, Prakash, Krisnamurthy A, et al. Anatomical variations of the thyroid gland: possible surgical implications. Singapore Med J. 2008; 49(10): 831-4.

5. Radkowski D, Arnold J, Healy GB, McGill T, Treves ST, Paltiel H, et al. Thyroglossal duct remnants. Preoperative evaluation and management. Arch Otolaryngol Head Neck Surg. 1991; 117(12): 1378-81.

5. Braun EM, Windisch G, Wolf G, Hausleitner L, Anderhuber F. The pyramidal lobe: clinical anatomy and its importance in thyroid surgery. Surg Radiol Anat. 2007; 29(1): 21-7. 